\title{
Mercury in Amazonian fish from Madeira River basin, Rondônia State, Brazil
}

\author{
P. A. S. Gali ${ }^{1}$, D. M. Bonotto ${ }^{1}$, E. G. da Silveira ${ }^{2} \&$ W. R. Bastos ${ }^{2}$ \\ ${ }^{1}$ Departamento de Petrologia e Metalogenia, \\ Instituto de Geociências e Ciências Exatas-UNESP, Rio Claro, Brazil \\ ${ }^{2}$ Departamento de Geografia, \\ Fundação Universidade Federal de Rondônia-UNIR, Porto Velho, Brazil
}

\begin{abstract}
This investigation was carried out at the Madeira River basin, located in the state of Rondônia, Brazilian Amazon. Fish from Madeira, Jaciparaná, and Jamari rivers between 7 and $11^{\circ}$ parallels south and between 62 and $65^{\circ}$ meridians west in Rondônia state, Brazil, were sampled and chemically analyzed for mercury in order to evaluate if the inputs of this metal into the food-chain is occurring in levels reaching values above those recommended by the World Health Organization. This is because such an element is very dangerous when ingested by humans and its presence was extensively identified some years ago in the area, since it was utilized as an amalgam in processes for recovering alluvial gold.

Keywords: mercury, fish, statistical distribution, Madeira River basin, health hazard.
\end{abstract}

\section{Introduction}

In aquatic systems, heavy metals (including mercury) and other elements are mainly transported in the solid phase, either sorbed onto particle surfaces and coatings, or incorporated into mineral grains. Thus, 90-99 percent of the total metal load in rivers is transported in the particulate phase, depending on the geochemical behavior of the metal and the nature of the physical and chemical environment [1]. Upon discharge to river waters, metal speciation or complexation, and other physical-chemical parameters such as $\mathrm{pH}$, redox conditions, and nature of the solid-metal species interaction, determine the partitioning of the metal between solid and liquid phases, controlling its 
dispersion throughout the aquatic environment, where adsorption on fine particles has been recognized as a key process in its transport [2-4].

The sources of trace metals in aquatic systems determine their distribution ratio between the aqueous and solid phases, when the metal contents of river solids depend significantly on allochthonous influences. Mining activities involve the extraction, processing, and disposal of large quantities of rock, being responsible, very often, by the release of metals that are introduced either directly or indirectly to rivers and streams [5]. The major problem affecting mercury during mining activities is related to the fact that it is widely utilized as an amalgam in processing alluvial gold ores, mainly in rainforest areas [6, 7].

The gold exploitation in several areas of the Brazilian Amazon has caused environmental problems due to the presence of mercury in the biosphere, whether in liquid, ionic or vapour form. Special attention has been given to mercury inputs at the Madeira River in the Amazon area by numerous investigators $[6,8-13]$ since is one of the largest tributary of Amazon River and the gold mining was officially allowed and practiced since the Andean headwaters, causing the release of metallic mercury to the atmosphere and waterways [14].

The gold mining activities on the Madeira River extended from the Bolivian headwaters, on the Beni River, down to the city of Porto Velho, capital of Rondônia State, and, despite to be practically absent in the present days, mercury has been evaluated in the aquatic system by local authorities and environmentalists due to the possibility of occurring contamination in people [15]. Contamination of the aquatic food-chain of the Madeira River tributaries has been demonstrated [20], being reported that $86 \%$ of the piscivorous fish collected in the Beni River exhibited high mercury concentrations, i.e. values exceeding by almost four times the WHO safety limit [16].

This investigation focused the mercury presence in fish of the Madeira River basin, Brazilian Amazon, following the previous interest in the area due to possible intoxication on animal and human population due to the ingestion of this metal in food.

\section{Material and methods}

The Madeira River is one of the largest tributaries of the Amazon River, extending from Bolívia and crossing the city of Porto Velho, capital of Rondônia State in Brazil, which is the most populated site (population approximately 300,000 , according to the 1999 census) along it. The Aw-tropical rainy climate (Köppen classification) characterizes Rondônia State, i.e. the relative air humidity ranges from 74.2 up to $90.8 \%$ and air temperature from 20.7 up to $32.2^{\circ} \mathrm{C}$ [17]. The wet season (average rainfall $=250 \mathrm{~mm} / \mathrm{month}$ ) occurs between October and April, whereas the dry season (average rainfall $=20 \mathrm{~mm} / \mathrm{month}$ ) between May and September [17]. Such rain regime influences directly the water level height of the Madeira River (Fig. 1).

This study provided $\mathrm{Hg}$ distribution data for 419 samples of fish from Madeira, Jaciparaná, and Jamari rivers in the Madeira River basin between 7 and 
$11^{\circ}$ parallels south and between 62 and $65^{\circ}$ meridians west in Rondônia state, Brazil (Fig. 2). The samples were obtained between April 1994 and January 1998 in the central market located at the city of Porto Velho, as well collected directly from the rivers after using roads and small boats, because the selected area is not suitable for navigation. The specimens were identified according to their popular name during the fieldwork. Afterwards, they were stored in polyethylene bags that were kept in iceboxes and transported up to the laboratory.

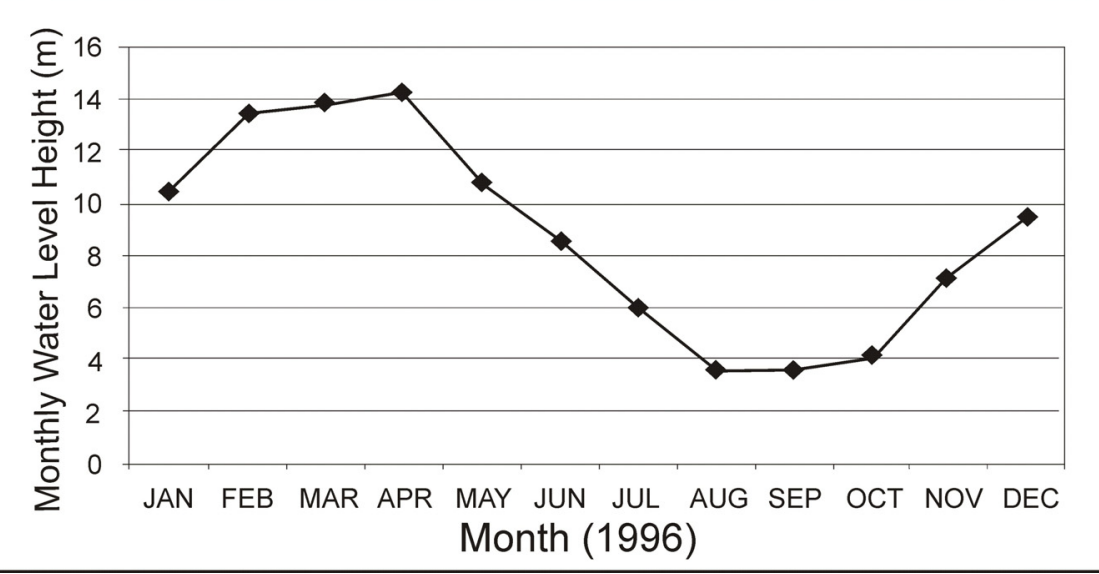

Figure 1: The average monthly water level height of the Madeira River during 1996 [17].

The weight and length of the specimens were recorded at the laboratory according to standard procedures [18]. It was also indicated if their skin contains scales or not, as well their possible scientific name based on criteria applied to Amazonian fish [18]. Then, a fillet was cut from the back of the specimen and maintained under freeze $\left(-5^{\circ} \mathrm{C}\right)$ up to the time of analysis.

Digestion and extraction procedures were used for $\mathrm{Hg}$ analysis in the samples. About $0.5 \mathrm{~g}$ of each sample was weighed in Teflon beakers/tubes, $1 \mathrm{~mL}$ of $30 \%$ $\mathrm{H}_{2} \mathrm{O}_{2}$ was added plus $2 \mathrm{~mL}$ of a $1: 1 \mathrm{H}_{2} \mathrm{SO}_{4}-\mathrm{HNO}_{3}$ mixture and $5 \mathrm{~mL}$ of $5 \%$ $\mathrm{KMnO}_{4}$. This material was inserted in a $630 \mathrm{~W}$ microwave oven and maintained there (temperature $55^{\circ} \mathrm{C}$ ) during about 35 minutes. Alternatively, digestion was also performed in an opened system. Afterwards, the solution was brought to room temperature $\left(\sim 25^{\circ} \mathrm{C}\right)$ and the excess $\mathrm{KMnO}_{4}$ was neutralized with some drops of $12 \%$ hydroxylamine hydrochlorate. The volume was raised up to $10 \mathrm{~mL}$ with ultra pure water prepared on a Milli Q system that uses ion exchange resin and Millipore $0.22 \mu \mathrm{m}$ filter.

The analyses of total $\mathrm{Hg}$ concentrations were done using atomic absorption spectrophotometers with cold vapor generation. The equipment utilized is a Perkin Elmer model FIMS-400 atomic absorption spectrophotometer, containing a cylindrical cell with quartz window, an $\mathrm{Hg}$ lamp $(253.7 \mathrm{~nm})$, a specific detector 
for absorption on the $\mathrm{Hg}$ wavelength, a system of flow injection analysis, and a cold vapor generator system. The parameters of calibration utilized in this equipment consisted on an $\mathrm{Ar}$ flow of $50 \mathrm{~mL} \cdot \mathrm{min}^{-1}$, a $3 \% \mathrm{HCl}$ flow of 9-11 mL. $\mathrm{min}^{-1}$, and a $0.2-0.5 \% \mathrm{NaBH}_{4}+\mathrm{NaOH}$ flow of 5-7 mL. $\mathrm{min}^{-1}$. The concentrations of the analytical solutions for obtaining the calibration curve of the equipment varied between 2 and $40 \mu \mathrm{g} . \mathrm{L}^{-1}$, and were prepared from a $2 \mu \mathrm{g} \cdot \mathrm{mL}^{-1}$ stock solution preserved with $5 \% \mathrm{HNO}_{3}+0.01 \% \mathrm{~K}_{2} \mathrm{Cr}_{2} \mathrm{O}_{7}$. Each aliquot representing the sample $(0.5 \mathrm{~g})$ was divided in three sub-aliquots. All analytical determinations were made in triplicate for each sub-aliquot, yielding, therefore, nine measurements for each sample. The final result for each sample (Table 1) corresponded to the mean value of the nine readings.

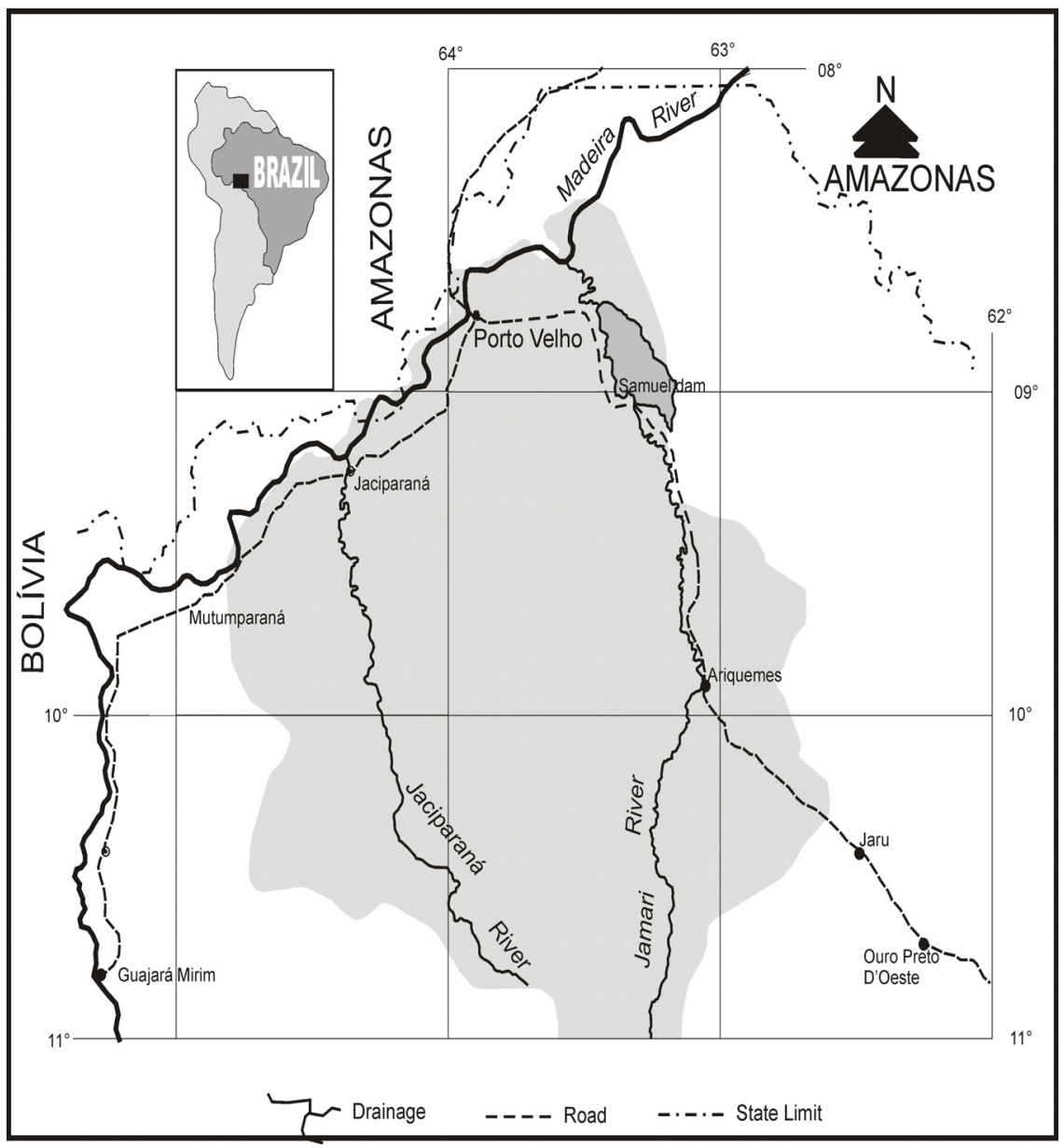

Figure 2: $\quad$ Location of the area for sampling fish in Rondônia State, Brazil. 
Table 1: Average Hg content in fish from the Madeira River basin, Brazil.

\begin{tabular}{|c|c|c|c|}
\hline Popular name & Scientific name & $\mathrm{N}^{*}$ & $\mathrm{Hg}(\mathrm{ppm})$ \\
\hline Acará & Geophagus sp. & 10 & 0.09 \\
\hline Acari Bodó & Lipsarcus pardalis & 1 & 0.04 \\
\hline Apapá & Pellona sp. & 1 & 0.81 \\
\hline Aruanã & Osteoglossum bicirrhossum & 2 & 0.68 \\
\hline Bacu & Pterodoras granulosus & 1 & 0.01 \\
\hline Bico de Pato & Hemisorubim platyrhynchos & 3 & 0.53 \\
\hline Bicudo & Boulengerella ocellata & 4 & 0.90 \\
\hline Branquinha & Potamorhina latior & 16 & 0.09 \\
\hline Cará & Cichlasoma spectabile & 3 & 0.29 \\
\hline Caratinga & Not identified & 1 & 0.04 \\
\hline Cascudinho & Pareiorhapis duseni & 7 & 0.04 \\
\hline Cascudo & Plecostomus sp. & 3 & 0.04 \\
\hline Croatá & Platynematichthys notatus & 2 & 1.86 \\
\hline Curimatã & Prochilodus sp. & 38 & 0.12 \\
\hline Curimba & Not identified & 1 & 0.08 \\
\hline Dourado & Brachyplathystoma flavicans & 4 & 0.43 \\
\hline Filhote & $\begin{array}{l}\text { Brachyplathystoma } \\
\text { filamentosum }\end{array}$ & 7 & 0.96 \\
\hline Jacundá & Crenicichla reticulata & 5 & 0.37 \\
\hline Jaraqui & Semaprochilodus taeniurus & 7 & 0.18 \\
\hline Jatuarana & Hemiodus notatus & 9 & 0.10 \\
\hline Jaú & Paulicea leutkeni & 2 & 0.52 \\
\hline Lírio Braço de Moça & Platystomatichthys sturio & 4 & 0.46 \\
\hline Mandi & Pimelodus sp. & 6 & 0.34 \\
\hline Mandubé & Ageneiosus brevifilis & 3 & 0.95 \\
\hline Mapará & Hypophtalmus edentatus & 18 & 0.56 \\
\hline Matrinchã & Brycon sp. & 1 & 0.05 \\
\hline Pacu & Mylossoma sp. & 21 & 0.07 \\
\hline Peixe Cachorro & Hydrolycus scomberoides & 9 & 0.97 \\
\hline Pescada & Plagioscion squamosissimus & 14 & 0.33 \\
\hline Piau & Laemiyta sp. & 4 & 0.07 \\
\hline Piau Apará & Not identified & 3 & 0.21 \\
\hline Piau Aracu & Laemolyta sp. & 6 & 0.16 \\
\hline Piau Botafogo & Shizodon vittatum & 3 & 0.04 \\
\hline Piau Cabeça Gorda & Leporinus friderici & 5 & 0.20 \\
\hline Piau Cabeça de Meia & Schizodon fasciatum & 14 & 0.14 \\
\hline Pintado & Pseudoplatystoma sp. & 22 & 0.92 \\
\hline Piramutaba & Brachyplathystoma vaillanti & 1 & 0.09 \\
\hline Piranha & Serrasalmus sp. & 46 & 0.80 \\
\hline Pirapitinga & Colossoma bidens & 3 & 0.08 \\
\hline Pirarucu & Arapaima gigas & 4 & 0.26 \\
\hline Sardinha & Triportheus elongatus & 11 & 0.26 \\
\hline Surubim & Pseudoplatystoma fasciatus & 1 & 0.38 \\
\hline Tambaqui & Colossoma macropomum & 8 & 0.15 \\
\hline Traíra & Hoplias malabaricus & 34 & 0.46 \\
\hline Tucunaré & Cichla ocellaris & 49 & 0.36 \\
\hline Tucunaré açu & Cichla sp. & 2 & 0.30 \\
\hline
\end{tabular}

$* \mathrm{~N}=$ number of samples. 


\section{Hg content in selected fish}

The average values of the $\mathrm{Hg}$ content in the analyzed fish are greatly variable, ranging from 0.01 to $1.86 \mathrm{ppm}$ (Table 1). The species sampled are widely spread over the area, being commonly consumed by the population. However, considering the number of specimens sampled per specie, the economic importance and the use in alimentation, four types were selected for initial evaluation of the data obtained. They are: Prochilodus sp., Serrasalmus sp., Hoplias malabaricus, and Cichla ocellaris. A summary of the parameters obtained for these fish is shown in Table 2.

The WHO safety limit [16] for ingestion of mercury in fish is $0.5 \mathrm{ppm}$ and considering the range of values reported in Table 2, only the specimens of Prochilodus sp. do not reach the maximum allowable limit in any analyzed sample. These fish ingest organic matter and microorganisms associated to mudstone at the bottom of lakes and margins of rivers, realizing long migration for reproduction. Serrasalmus sp., Hoplias malabaricus, and Cichla ocellaris are classified as carnivorous fish, and among them the average Hg content is higher in Serrasalmus sp. (0.8 ppm) that exceeds the WHO safety limit of $0.5 \mathrm{ppm}$.

However, such contamination level is lower than that found in other piscivorous fish in the Amazon area, since values exceeding by almost four times the WHO safety limit have been reported [8]. The same relationship between the $\mathrm{Hg}$ content and the alimentation pattern of the specie had been identified in previous studies developed in Brazil, with the higher $\mathrm{Hg}$ contents occurring in individuals of higher trophic levels [10-13].

Table 2: Weight, length, and Hg content in fish from the Madeira River basin, Rondônia State Brazil.

\begin{tabular}{ccccc}
\hline & Serrasalmus sp. & Prochilodus sp. & $\begin{array}{c}\text { Hoplias } \\
\text { malabaricus }\end{array}$ & $\begin{array}{c}\text { Cichla } \\
\text { ocellaris }\end{array}$ \\
$\begin{array}{c}\text { Number of } \\
\text { samples }\end{array}$ & 46 & 38 & 34 & 49 \\
\hline Minimum value & 500 & Weight $(\mathrm{g})$ & 250 & 100 \\
Maximum value & 2100 & 200 & 1200 & 2000 \\
Average value & 884 & 2000 & 533 & 560 \\
\hline Minimum value & 14 & Length $(\mathrm{cm})$ & & \\
Maximum value & 36.5 & 22 & 20.5 & 21 \\
Average value & 27 & 42.5 & 46 & 44 \\
\hline Minimum value & 0.1908 & 28 & 31 & 29 \\
Maximum value & 2.1681 & $\mathrm{Hg}(\mathrm{ppm})$ & & \\
Average value & 0.8051 & 0.0029 & 0.1018 & 0.0627 \\
\hline
\end{tabular}




\section{Statistical analysis of the data}

The Hg content data obtained for Prochilodus sp., Serrasalmus sp., Hoplias malabaricus, and Cichla ocellaris were submitted to statistical analysis, as reported in Table 3. All data adjust to a normal distribution (Fig. 3), inclusive those obtained for Cichla ocellaris that indicate a bi-modal normal distribution.

Table 3: Statistical distribution of the mercury content in fish from the Madeira River basin, Rondônia State, Brazil.

\begin{tabular}{|c|c|c|c|c|}
\hline $\begin{array}{l}\text { Hg content range } \\
(\mathrm{ppm})\end{array}$ & $\begin{array}{c}\text { Average } \mathrm{Hg} \\
\text { content } \\
(\mathrm{ppm})\end{array}$ & Frequency & $\begin{array}{l}\text { Frequency } \\
\text { percentage }\end{array}$ & $\begin{array}{l}\text { Cumulative } \\
\text { percentage }\end{array}$ \\
\hline \multicolumn{5}{|c|}{ Serrasalmus sp. $(\mathrm{N}=46)$} \\
\hline $0.1908-0.2861$ & 0.2400 & 4 & 8.7 & 8.7 \\
\hline $0.2861-0.4289$ & 0.3600 & 3 & 6.5 & 15.2 \\
\hline $0.4289-0.6430$ & 0.5400 & 12 & 26.1 & 41.3 \\
\hline $0.6430-0.9641$ & 0.8000 & 15 & 32.6 & 73.9 \\
\hline $0.9641-1.4456$ & 1.2000 & 8 & 17.4 & 91.3 \\
\hline $1.4456-2.1675$ & 1.8100 & 3 & 6.5 & 97.8 \\
\hline $2.1675-3.2499$ & 2.7100 & 1 & 2.2 & 100.0 \\
\hline \multicolumn{5}{|c|}{ Prochilodus sp. $(\mathrm{N}=38)$} \\
\hline $0.0018-0.0040$ & 0.0029 & 1 & 2.6 & 2.6 \\
\hline $0.0040-0.0088$ & 0.0064 & 0 & 0 & 2.6 \\
\hline $0.0088-0.0194$ & 0.0141 & 0 & 0 & 2.6 \\
\hline $0.0194-0.0429$ & 0.0312 & 1 & 2.6 & 5.2 \\
\hline $0.0429-0.0948$ & 0.0689 & 8 & 21 & 26.2 \\
\hline $0.0948-0.2095$ & 0.1523 & 26 & 68.5 & 94.7 \\
\hline $0.2095-0.4630$ & 0.3366 & 2 & 5.3 & 100 \\
\hline \multicolumn{5}{|c|}{ Hoplias malabaricus $(\mathrm{N}=34)$} \\
\hline $0.1000-0.1506$ & 0.1253 & 2 & 5.9 & 5.9 \\
\hline $0.1506-0.2268$ & 0.1887 & 2 & 5.9 & 11.8 \\
\hline $0.2268-0.3416$ & 0.2842 & 11 & 32.3 & 44.1 \\
\hline $0.3416-0.5144$ & 0.4280 & 9 & 26.5 & 70.6 \\
\hline $0.5144-0.7747$ & 0.6445 & 4 & 11.8 & 82.4 \\
\hline $0.7747-1.1667$ & 0.9707 & 5 & 14.7 & 97.1 \\
\hline $1.1667-1.7570$ & 1.4618 & 1 & 2.9 & 100 \\
\hline \multicolumn{5}{|c|}{ Cichla ocellaris $(\mathrm{N}=49)$} \\
\hline $0.0500-0.0771$ & 0.0636 & 1 & 2 & 2 \\
\hline $0.0771-0.1189$ & 0.0980 & 1 & 2 & 4 \\
\hline $0.1189-0.1833$ & 0.1511 & 9 & 18.5 & 22.5 \\
\hline $0.1833-0.2827$ & 0.2331 & 14 & 28.6 & 51.1 \\
\hline $0.2827-0.4359$ & 0.3594 & 6 & 12.2 & 63.3 \\
\hline $0.4359-0.6722$ & 0.5542 & 15 & 30.6 & 93.9 \\
\hline $0.6722-1,0366$ & 0.8547 & 3 & 6.1 & 100 \\
\hline
\end{tabular}

Statistical tests of correlation were performed between weight and length and between the $\mathrm{Hg}$ content and weight for the data obtained for Prochilodus sp., Serrasalmus sp., Hoplias malabaricus, and Cichla ocellaris. Fig. 4 plots all 
relationships found among these parameters, where it is possible to see that the weight of the specimens is directly related to their length, as expected. The $\mathrm{Hg}$ content raises in accordance with the weight of the carnivorous fish Serrasalmus sp., Hoplias malabaricus, and Cichla ocellaris (Fig. 4), evidencing the cumulative effect of mercury in tissues, i.e. the increase in weight is normally related to the age of the specimen, that causes a longer assimilation of $\mathrm{Hg}$ present in food, not in the metallic form, but bio-available in the ionized (organic) form. Beyond the $\mathrm{Hg}$ content values in the non-piscivorous fish Prochilodus sp. not exceed the WHO safety limit of $0.5 \mathrm{ppm}$, the $\mathrm{Hg}$ content and weight in these fish are not related (Fig. 4), reinforcing the importance of the alimentation habit on the $\mathrm{Hg}$ bioaccumulation.
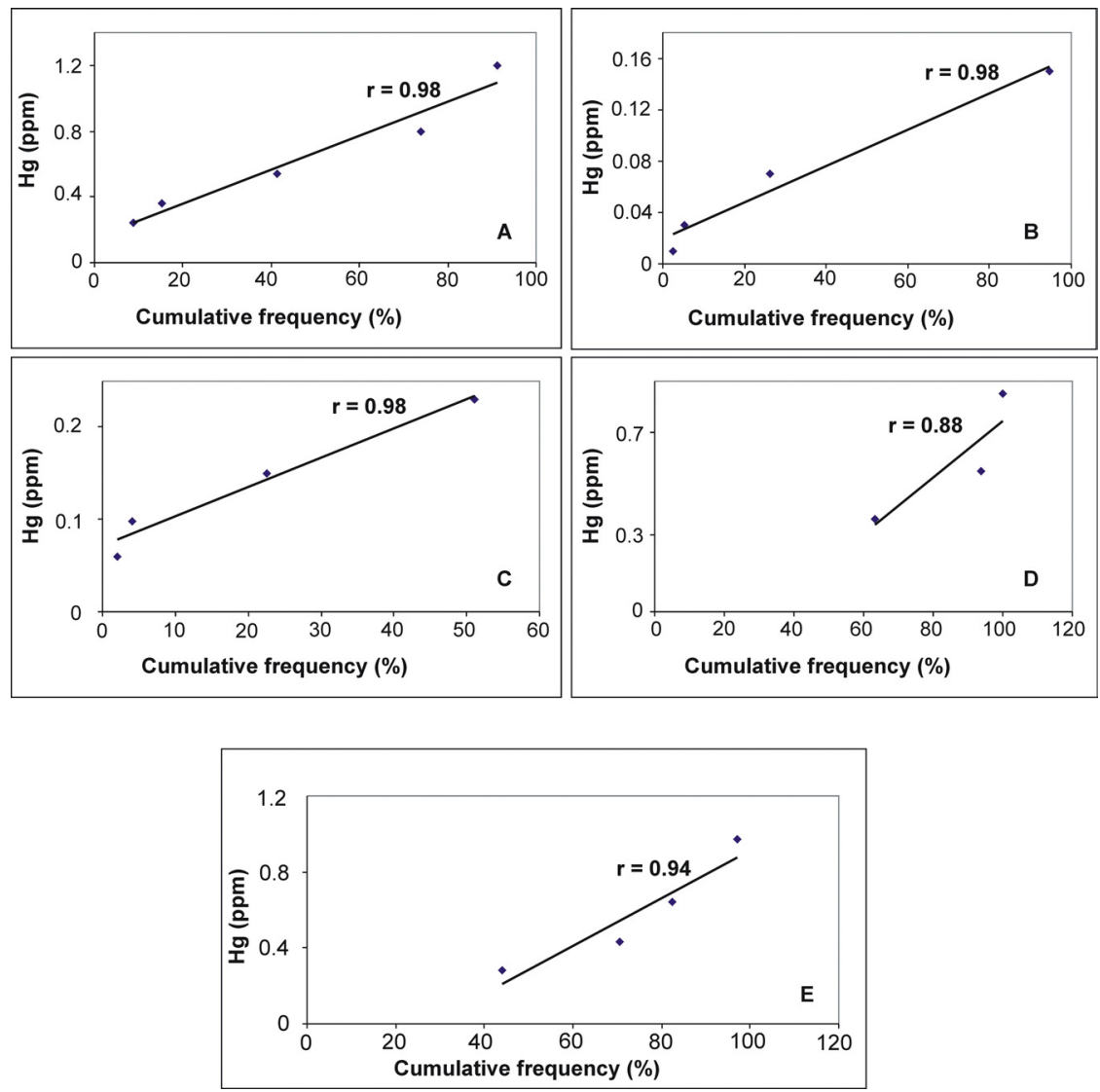

Figure 3: The average Hg content in a) Serrasalmus sp., b) Prochilodus sp., c) Cichla ocellaris $(\mathrm{N}=25)$, d) Cichla ocellaris $(\mathrm{N}=24)$, and e) Hoplias malabaricus plotted on a probability graph. 

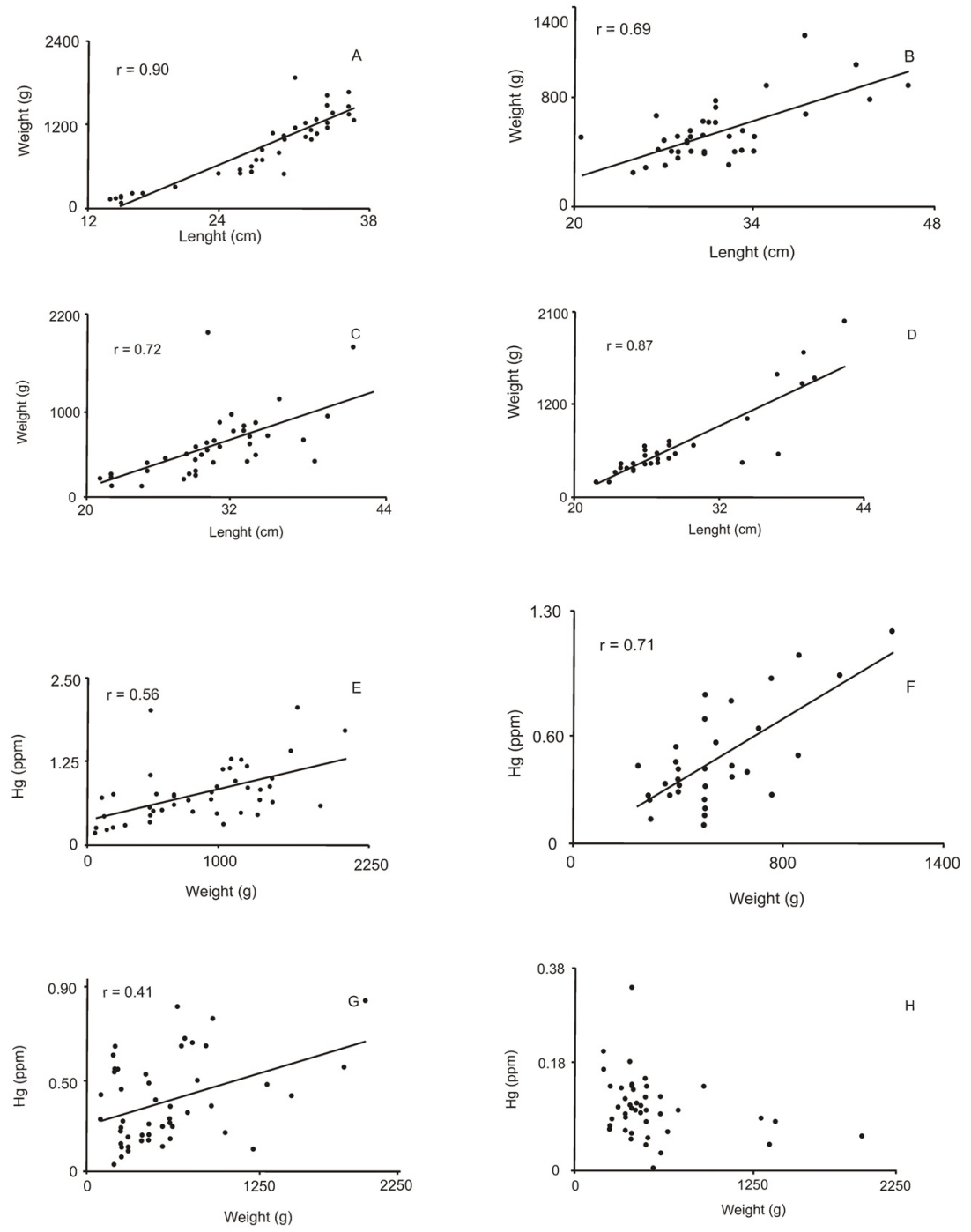

Figure 4: The relationship between weight and length in a) Serrasalmus sp., b) Hoplias malabaricus, c) Cichla ocellaris, d) Prochilodus sp., and the relationship between the $\mathrm{Hg}$ content and weight in e) Serrasalmus sp., f) Hoplias malabaricus, g) Cichla ocellaris, and h) Prochilodus sp. 


\section{References}

[1] Miller, J.R., The role of fluvial geomorphic processes in the dispersal of heavy metals from mine sites. J. Geochem. Explor., 58, pp.101-118, 1997.

[2] Lockwood, R.A. \& Chen, K.Y., Adsorption of $\mathrm{Hg}$ (II) by hydrous manganese oxides. Environ. Sci. Technol., 7, pp. 1028-1034, 1973.

[3] Gambrel, R.P., Khalid, R.A. \& Patrick Jr., W.H., Chemical availability of $\mathrm{Hg}, \mathrm{Pb}$, and $\mathrm{Zn}$ in mobile bay sediment suspensions as affected by $\mathrm{pH}$ and oxidation-reduction conditions. Environ. Sci. Technol.,14,.431-436, 1980.

[4] Luoma, S.N., Bioavailability of trace metals to aquatic organisms - a review. Sci. Total Environ., 28, pp. 1-22, 1983.

[5] Salomons, W. \& Förstner, U., Metals in the hydrocycle, Springer-Verlag: Berlin, 353 p., 1984.

[6] Pfeiffer, W.C., Lacerda, L.D., Malm, O., Souza, C.M.M., Silveira, E.G. \& Bastos, W.R., Mercury concentrations in inland waters of gold-mining areas in Rondônia, Brazil. Sci. Total Environ., 87, pp. 233-240, 1989.

[7] Cramer, S.W., Problems facing the Philippines. Int. Min., pp. 29-30, 1990.

[8] Maurice-Bourgoin,L., Quiroga,I., Chincheros, J. \& Courau,P. Mercury distribution in waters and fish of the upper Madeira rivers and mercury exposure in riparian Amazonian populations. Sci.Total Environ,260, 73-86, 2000.

[9] Lacerda, L.D., Amazon mercury emissions. Nature, 374, pp. 21-22, 1995.

[10] Malm, O., Pfeiffer, W.C., Souza, C.M.M., \& Reuter, R., Mercury pollution due to gold mining in the Madeira River basin. Ambio, 19, pp.11-15, 1990.

[11] Malm, O., Contaminação ambiental e humana por mercúrio na região garimpeira de ouro do Rio Madeira, PhD Thesis, Universidade Federal do Rio de Janeiro: Rio de Janeiro, 1991.

[12] Lacerda, L.D., Pfeiffer, W.C., Ott, A.T. \& Silveira, E.G., Mercury contamination in the Madeira River, Amazon: mercury inputs to the environment. Biotropica, 21, pp. 91-93, 1989.

[13] Pfeiffer, W.C. \& Lacerda, L.D., Mercury inputs into the Amazon region, Brazil. Environm. Technol. Lett., 9, pp. 325-330, 1988.

[14] Azcue, J.M., Guimarães, J.R.D., Mudroch, A, Mudroch, P., \& Malm, O., Bottom and suspended sediment sampling for studies on the behavior of mercury and other heavy metals in southwestern Amazon rivers and a reservoir, Brazil. Handbook of techniques for aquatic sediments sampling, eds. A. Mudroch, \& S.D. MacKnight, CRC Press: Boca Raton, pp. 203-228, 1994.

[15] Cleary, D., Thornton, I.L., Brown, N., Kazantzis, G., Delves, T. \& Worthington, S, Mercury in Brazil. Nature, 369, pp. 613-614, 1994.

[16] WHO (World Health Organization), Environmental Health Criteria - I. Mercury. Geneva, pp. 1-131, 1976.

[17] Nunes, D.D., Hidrovia do rio Madeira. Research Report PIBICUNIR/CNPq, Universidade Federal de Rondônia: Porto Velho, 1999.

[18] Santos, G.M., Pesca e ecologia dos peixes de Rondônia, PhD Thesis, Instituto Nacional de Pesquisas da Amazônia: Manaus, 213 p., 1991. 